\title{
Tromboliza w ostrej zatorowości płucnej bez hipotensji - sukces kliniczny i elektrokardiograficzny
}

\author{
Thrombolysis in acute pulmonary embolism without hypotension \\ - clinical and electrocardiographical success
}

\author{
Marcin Koć, Piotr Bienias \\ Klinika Chorób Wewnętrznych i Kardiologii z Centrum Diagnostyki i Leczenia Żylnej Choroby Zakrzepowo-Zatorowej \\ Warszawskiego Uniwersytetu Medycznego
}

\section{Streszczenie}

Mimo coraz lepszych możliwości diagnostycznych i terapeutycznych ostra zatorowość płucna (APE) pozostaje istotnym problemem klinicznym. Do oceny ciężkości choroby wykorzystuje się liczne badania, w tym obrazowe i laboratoryjne. Niestety, często pomijana jest technika dostępna w większości punktów medycznych, w przypadku której na wynik trzeba czekać nie dłużej niż kilka minut - badanie elektrokardiograficzne (EKG). W przedstawionym przypadku autorzy przypomnieli typowe elektrokardiograficzne cechy APE, przybliżyli możliwość pośredniej stratyfikacji ryzyka na podstawie zapisów EKG u chorych z APE, a także, nieco obok kwestii związanych z EKG, zwrócili uwagę na zmiany w leczeniu chorych na APE wprowadzone w najnowszych wytycznych dotyczących diagnostyki i leczenia tej choroby.

Słowa kluczowe: elektrokardiografia, ostra zatorowość płucna, tromboliza

Folia Cardiologica 2015; 10, supl. C: 18-20

\section{Opis przypadku}

Kobieta w wieku 56 lat, po niedawno przebytym złamaniu kości udowej leczonym operacyjnie, została skierowana do szpitala z powodu narastającej od 3 dni duszności spoczynkowej oraz nawracających bólów w klatce piersiowej. W wykonanych na szpitalnym oddziale ratunkowym (SOR) badaniach stwierdzono podwyższone do $0,7 \mathrm{ng} / \mathrm{ml}$ (norma $<0,2 \mathrm{ng} / \mathrm{ml}$ ) stężenie troponiny I oraz masywną radiologicznie ostrą zatorowość płucną (APE, acute pulmonary embolism) w angiografii tomografii komputerowej klatki piersiowej. Przy przyjęciu na oddział intensywnej opieki kardiologicznej (OIOK) chora była w stanie średnio ciężkim, z nasiloną dusznością i tachypnoe 30/min. W zapisie elektrokardiograficznym (EKG) (ryc. 1) stwierdzono tachykardię zatokową 120/min, pośrednią oś serca, zespół S1Q3T3 (objaw McGinna-White'a), graniczne uniesienie odcinka ST w odprowadzeniu III, ujemny załamek T w odprowadzeniach V1-V3 oraz zespoły QS i istotne uniesienie odcinka ST w odprowadzeniach prawokomorowych - nieprawidłowości typowe dla ostrego przeciążenia prawej komory w przebiegu APE [1]. Oprócz wartości diagnostycznej objawy te moga mieć również znaczenie rokownicze, służąc określeniu ryzyka wczesnego zgonu i/lub ostrej dysfunkcji prawej komory. Obok tachykardii zatokowej i całkowitego lub niezupełnego bloku prawej odnogi pęczka Hisa wchodzą w skład, przeznaczonej do oceny tego ryzyka, skali punktowej zaproponowanej przez Daniela i wsp. [2]. Uniesienie odcinka ST w odprowadzeniu III jest zarówno kolejną cechą sugerującą rozpoznanie APE, jak i cechą służącą do stratyfikacji ciężkości choroby. Kukla i wsp. [3] zwrócili uwagę na obecność tej cechy (obok wyżej wspomnianych

Adres do korespondencji: lek. Marcin Koć, Klinika Chorób Wewnętrznych i Kardiologii, Warszawski Uniwersytet Medyczny, Szpital Kliniczny Dzieciątka Jezus, ul. Lindleya 4, 02-005 Warszawa, tel. 2250211 44, faks 2250221 42, e-mail: marcin.koc@wum.edu.pl 


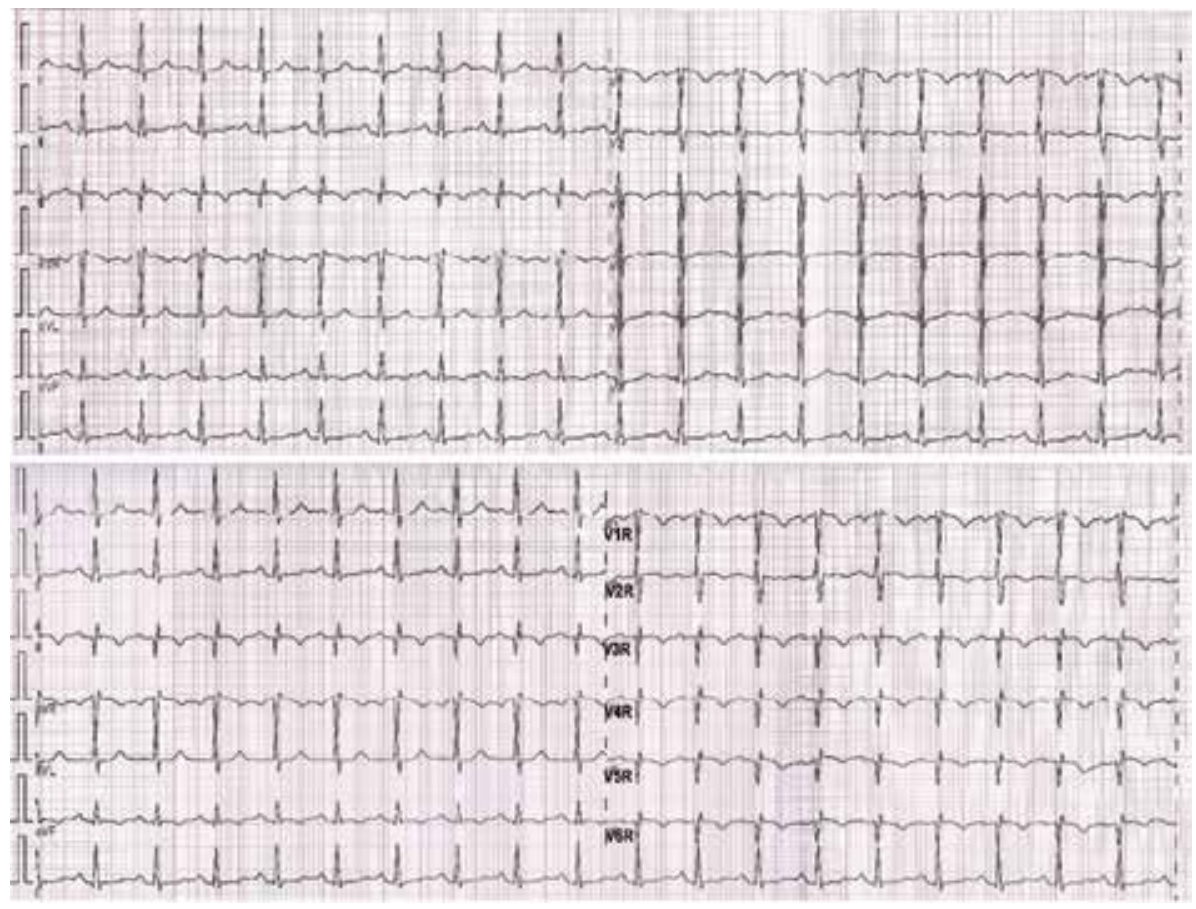

Rycina 1. Zapis elektrokardiograficzny przy przyjęciu; opis w tekście

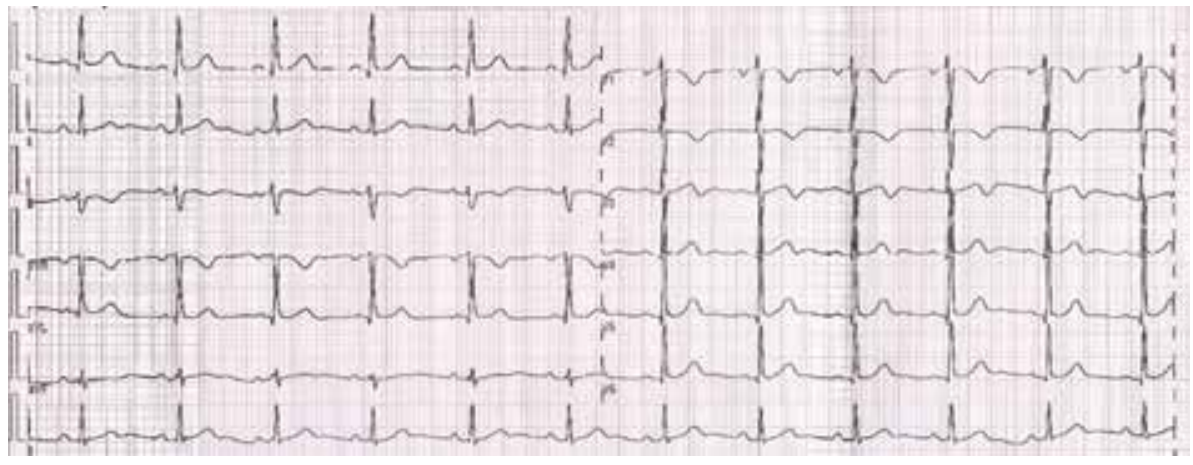

Rycina 2. Zapis elektrokardiograficzny w 2 . dobie po zastosowaniu trombolizy

ujemnych załamków T w odprowadzeniach V1-V4 oraz zespołu S1Q3T3) jako czynnika prognostycznego gorszego przebiegu APE. Wszystkie te elektrokardiograficzne objawy ostrego przeciążenia/niedokrwienia prawej komory serca pozwoliły zaliczyć opisywaną chorą do grupy podwyższonego ryzyka wczesnego zgonu.

\section{Omówienie}

Ze względu na stałe pogarszanie się stanu chorej oraz narastającą niewydolność oddechową mimo intensywnej tlenoterapii i leczenia heparyną niefrakcjonowaną we wlewie zadecydowano o zastosowaniu leczenia trombolitycznego rekombinowanym tkankowym aktywatorem plazminogenu
(rt-PA, recombinant tissue plasminogen activator) (mimo braku hipotensji). Uzyskano szybką poprawę stanu klinicznego, zapisu EKG i obrazu echokardiograficznego. W aktualnych wytycznych European Society of Cardiology (ESC), dotyczących diagnostyki i leczenia APE z 2014 roku, dotychczasowe wskazania do leczenia reperfuzyjnego rozszerzono o grupę chorych pośredniego-wysokiego ryzyka (bez wstrząsu i hipotensji) - klasa Ila (tromboliza), Ilb (reperfuzja interwencyjna) [4]. W 2. dobie po podaniu rt-PA w EKG obserwowano (ryc. 2) ustąpienie cech przeciążenia prawej komory, co potwierdzono w badaniu echokardiograficznym. W dniu wypisania ze szpitala (7. doba od zastosowania trombolizy) zapis EKG uległ całkowitej normalizacji (ryc. 3). Wydaje się, że mimo coraz większej 


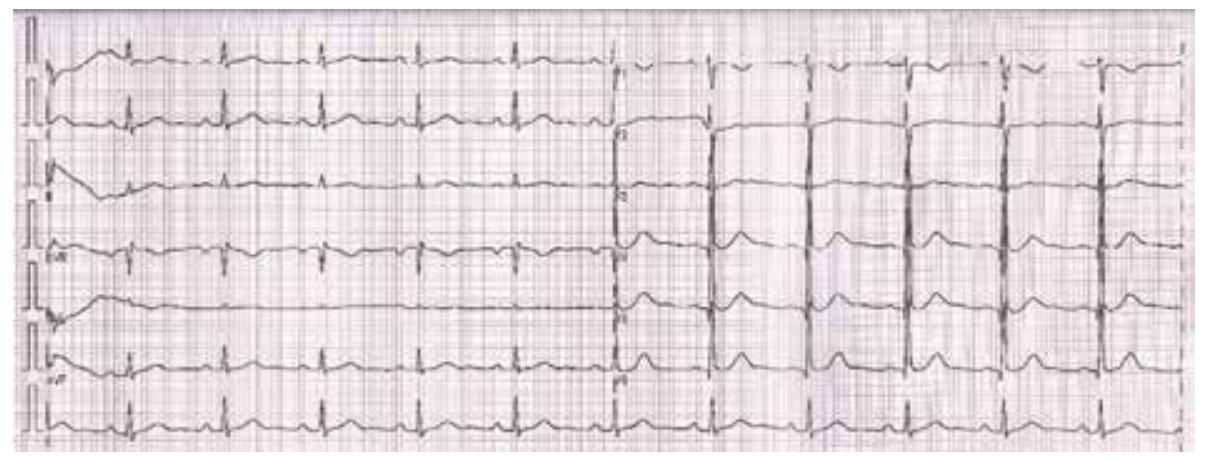

Rycina 3. Zapis elektrokardiograficzny przy wypisaniu ze szpitala

dostępności i wszechstronności badań obrazowych, EKG pozostaje niedocenianym narzędziem w stratyfikacji ryzyka chorych z APE.

\section{Konflikt interesów}

Autorzy deklarują brak konfliktu interesów.

\section{Abstract}

Despite better diagnostic and therapeutic possibilities, acute pulmonary embolism (APE) remains significant clinical problem. Many tests, including laboratory and visualizing are used to assess the prognosis. One of the most accessible and cheapest is unfortunately often omitted. This is the electrocardiogram (ECG). In the presented case we remind electrocardiographic signs of APE, we show possibility of indirect risk stratification based on ECG in patients with APE and, we would like to put the attention on changes in APE treatment guidelines.

Key words: electrocardiography, acute pulmonary embolism, thrombolysis

Folia Cardiologica 2015; 10, supl. C: $18-20$

\section{Piśmiennictwo}

1. Bienias P., Rymarczyk, Z. Badanie elektrokardiograficzne w zatorowości płucnej. W: Pruszczyk P., Ciurzyński M., Kostrubiec M. (red.). Żylna choroba zakrzepowo-zatorowa. Medical Tribune Polska, Warszawa 2012: 68-74.

2. Daniel K.R., Courtney D.M., Kline J.A. Assessment of cardiac stress from massive pulmonary embolism with 12-lead ECG. Chest 2001; 120: 474-481
3. Kukla P., Dlugopolski R., Krupa E. i wsp. Electrocardiography and prognosis of patients with acute pulmonary embolism. Cardiol. J. 2011; 18: 648-653.

4. Konstantinides S.V., Torbicki A., Agnelli G. i wsp. 2014 ESC guidelines on the diagnosis and management of acute pulmonary embolism. Eur. Heart J. 2014; 35: 3033-3069, 3069a-3069k. 